\title{
Rubber world price transmission to Ivorian producer prices: an analysis in the presence of structural breaks
}

\author{
Mélanie Ahoba ${ }^{*}$ (D) and Frédéric Gaspart ${ }^{1}$
}

\author{
*Correspondence: \\ atte.ahoba@student.uclouvain.be \\ 'Department of Agricultural \\ Economics, Earth and Life Institute \\ (ELI), Université Catholique de \\ Louvain, Louvain-la-Neuve, Belgium
}

\begin{abstract}
This article analyzes the link between world prices and producer prices of rubber in Côte d'Ivoire. Using monthly data from 2006 to 2016, we gave special attention to structural breaks in the data and asymmetry in the transmission process. Empirical results validate the presence of two breaks in the data series, both in 2008 and 2011 corresponding to a general surge in commodity prices. A multivariate threshold vector error correction model (TVECM) allows us to test the presence of asymmetry. The results strongly support the linearity hypothesis against $k$-regime TVECM. From there, a linear VECM reveals that changes in rubber world prices are strongly transmitted to Ivorian producer prices. In case of a world price permanent decrease, this will be devastating for small producer incomes, since financial markets are essentially missing in those rural areas and switching costs for perennial crops are huge. Some recommendations are given to prevent such a crisis.
\end{abstract}

Keywords: Price transmission, Rubber, Threshold cointegration, Côte d'Ivoire, Structural breaks

\section{Background}

As many developing countries, Côte d'Ivoire experienced early in the 1990s the privatization of its export crops market. As part of the structural adjustment programs, this measure aimed at increasing the competitiveness of the export sector and offering to producers more incentive prices (Shepherd and Farolfi 1999). Before the 1990s, the export crop sector in Côte d'Ivoire was heavily regulated, with the involvement of the state at all levels of the production chain. The government was also in charge of regulating the prices through the marketing boards. During the liberalization, price stabilization schemes and the marketing boards were removed. One of the advantages of liberalization has been to allow producers to benefit from the increases in world prices, contrary to the stabilized prices under the former setting. On the other hand, liberalization also implies the entry of few big private processors (multinational companies). In fact, the sudden withdrawal of the government led to a more commercial system for which producers were not prepared. Thus, in most export crop sectors, the entry of these big private firms simply replaced a state monopoly by a private monopoly, leading to asymmetry in the world price transmission to producers (Subervie 2011).

(c) The Author(s). 2019 Open Access This article is distributed under the terms of the Creative Commons Attribution 4.0 International License (http://creativecommons.org/licenses/by/4.0/), which permits unrestricted use, distribution, and reproduction in any medium, provided you give appropriate credit to the original author(s) and the source, provide a link to the Creative Commons license, and indicate if changes were made. 
More than two decades after the liberalization reform, there is a need for a detailed research about the dynamics of producer prices. How are variations in world prices transmitted to the domestic market in Côte d'Ivoire? Is there asymmetry in the transmission process? How do price spikes, such as those experienced in 2008 and 2011 in agricultural commodity prices, influence the relationship between the world price and the price received by farmers? All these are questions to be answered to help policy-makers to be more effective in designing suitable policies to improve the welfare of small-scale farmers, living in rural areas and who mainly depend on export crops revenue.

It is important to mention that more than $50 \%$ of the whole Côte d'Ivoire rubber production comes from small producers (Ruf (2012), Kouame (2015)). From less than $100 \mathrm{t}$ in 1961, the national rubber production reached 119,000 $\mathrm{t}$ in 2002 and 270,000 $\mathrm{t}$ in 2013. Figure 1 depicts the evolution of both Ivorian rubber production and exports from 1980 to 2013 .

The Ivorian rubber sector experienced significant changes after liberalization. From a state-oriented sector, the rubber sector now includes, on one side, individual farmers who sell their raw product to agroindustrial firms (private processors), and on the other side, agroindustrial which buy the farmers' production and ensure the conditioning, before exporting the rubber mainly to East Asia and Europe. In order to face these large agroindustrial companies, small producers found it suitable to create one professional organization to defend their mutual interests and counterbalance the potential market power of private processors. Like rubber producers, private processors organized themselves into a professional organization. Subsequently, all the professional organizations came together into an umbrella organization: the Association of Natural Rubber Professionals in Côte d'Ivoire (APROMAC). Within APROMAC, the different stakeholders set up several professional agreements for regulating the sector, without government involvement. One of the objectives of these agreements was to ensure a fair remuneration for

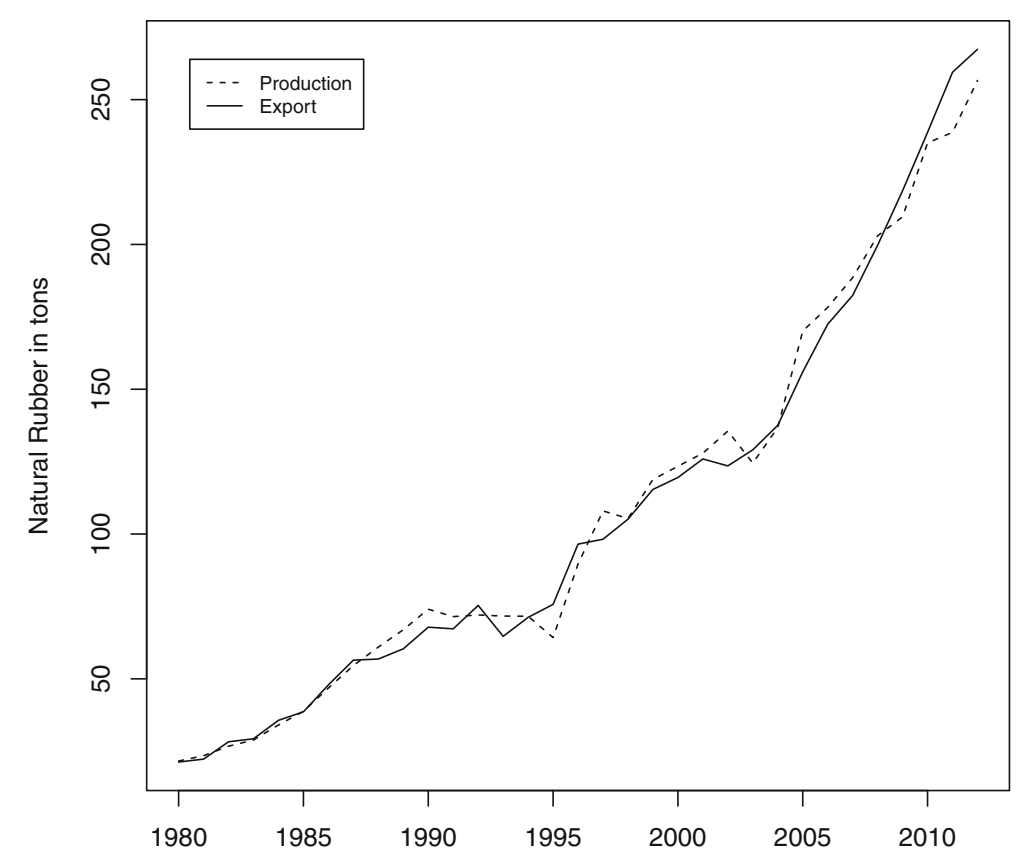

Fig. 1 Côte d'Ivoire natural rubber annual production and export from 1980 to 2012 
all actors. As a consequence of these agreements between the various actors (producers and processors), a high elasticity is expected for rubber world price transmission to producer prices, with no asymmetry in the transmission process, contrary to other Ivorian liberalized sectors. In fact, despite the operational challenges, the Ivorian rubber sector has been able to stand out from the other cash crop sectors thanks to a good organization (especially through APROMAC). In return, several taxes are paid by farmers to ensure a good management of their professional organizations. This could eventually raise a financial barrier to world price transmission, since these taxes are deducted from the producer price.

Moreover, given that the country only holds a marginal share of the world market, we do not expect Ivorian producer price to influence the world price. While the country share in the whole African production is around 50\%, it is still a marginal producer worldwide with a contribution around $2 \%$ of the world production. Most of the production is provided by South East Asia (e.g., Thailand, Indonesia, Vietnam) (MINADER 2016).

Agricultural price transmission from the world market to domestic markets has received much attention in the literature. However, studies focusing especially on world price transmission to producer prices for export crops in developing countries have received relatively scant attention, due partly to the lack of reliable data on producer prices in these countries. The results of studies on world price transmission to domestic prices in developing countries are generally mixed.

An earlier empirical paper of Mundlak and Larson (1992) investigated the relationship between the world and domestic prices for 58 countries and for the period 1961-1987. Using a linear regression to analyze the world price transmission, they found that most variations in world prices are transmitted and constitute the dominant component in the variations of domestic prices. Subervie (2007a) repeated a similar analysis for a postliberalization period. The results were heterogeneous. The elasticity was not significantly different from 0 in 16 out of 48 countries and lies between 0.18 and 1.4 for the countries where it was non-zero. However, for some products such as coffee and cocoa, elasticities were reasonably higher.

Beside the studies mentioned above, others tried to analyze the price transmission using cointegration techniques (e.g., Quiroz and Soto (1995), Minot (2010), Hazell et al. (1990), Baffes and Gardner (2003), Sharma (2003) von Cramon-Taubadel (2017)). In the vast majority of them, the tests do not systematically indicate the presence of a cointegration relationship between the producer price and the international price. For example, Minot (2010) found that less than a third of the 62 African prices tested showed a statistically significant link to the international prices and reported a median elasticity of 0.54 . The low values found for the elasticity in most of the developing countries are attributed to state policies, unfavorable market conditions such as weak infrastructures, and market power which are the major barriers to price transmission.

Another interest has been to examine the presence of asymmetry in the transmission process (Abdulai (2000), Subervie (2007b), Badolo (2011)). In his study, Badolo (2011) analyzed the transmission of international price shocks to domestic prices of imported rice in Burkina Faso. The asymmetric response found in the study has been explained partly by the commercial intermediaries who form an oligopolistic system and try to more quickly transmit international price increases to domestic prices than international price decreases. 
World price transmission to domestic markets in Côte d'Ivoire has not been widely studied. Existing studies are either not recent or focus mainly on cocoa and coffee or some staple food (Lloyd et al. (1999), Jutting (2005), Soumahoro (2017)). To the best of our knowledge, no evidence has been found on how rubber world prices are transmitted to the Ivorian domestic market. Hence, the purpose of this study is to investigate the link between the rubber world price and the producer price in Côte d'Ivoire. Apart from focusing on the rubber sector, another contribution of this paper is to analyze the consequences of world price spikes in the relationship between domestic and international prices. In fact, the rise in commodity prices of 2008 and 2011 renewed the debate on the transmission of international price shocks to domestic markets. Moreover, the increasing importance of rubber in the Ivorian economy and the dependence of thousands of farmers on rubber income make this concern relevant to focus on. The remainder of the paper is organized as follows. The "Data" section gives details about the data used for empirical analysis. The "Methods" section presents the methodology and all the models used for empirical evidence. Arguments about the choice of models are given as well. Empirical results are presented in the "Results and discussion" section. Finally, the "Conclusion" section concludes with some remarks and policy recommendations.

\section{Data}

Monthly rubber world prices $\left(P^{w}\right)$ and producer prices in Côte d'Ivoire $\left(P^{d}\right)$ from August 2006 to December 2016 were used in the analysis. World prices were extracted from the World Bank database. These time series are sourced from Singapore Commodity Exchange (SICOM) which is an international reference for rubber market. The use of an international reference price from Eastern Asia is relevant, as Malaysia is one of the top export partners of Côte d'Ivoire ${ }^{1}$.

Domestic prices considered are monthly prices paid to farmers. We did not use the export price here because the purpose is to analyze the link between the world price and the price received by farmers. In fact, producers do not export directly, and they sell their product to agroindustrial firms. Information on producer prices was provided by the umbrella organization of rubber sector in Côte d'Ivoire (APROMAC). Both prices are expressed in US Dollar per kilogram. Producer prices initially in local currency ${ }^{2}$ have been converted into USD using exchange rates from the Central Bank of West African States $(\mathrm{BCEAO})^{3}$. Figure 2 shows both international and producer prices of rubber from August 2006 to December 2016. One can see that both prices co-move during this period. The most striking feature of both series is that they are characterized by two important price spikes.

In fact, rubber prices maintain a growing trend between 2006 and 2008. This rise actually started in 2002 to reach a peak in 2008 . However, rubber prices saw a significant price decrease of more than 50\% between 2008 and 2009. Then, both prices recovered again to reach a historical peak in the beginning of 2011, more than 6 US dollar per kilogram for the world price. From there, both prices experienced a continuous decline. Increase in agricultural prices is not uncommon, but based on historical data, it is not usual for two important price spikes to occur within 3 years.

\footnotetext{
${ }^{1}$ https://wits.worldbank.org

${ }^{2}$ Local currency in Cote d'Ivoire is the XOF which has a fix parity with Euro of 1 Euro $=655,957$ XOF

${ }^{3}$ Available at http://edenpub.bceao.int/rapport.php
} 


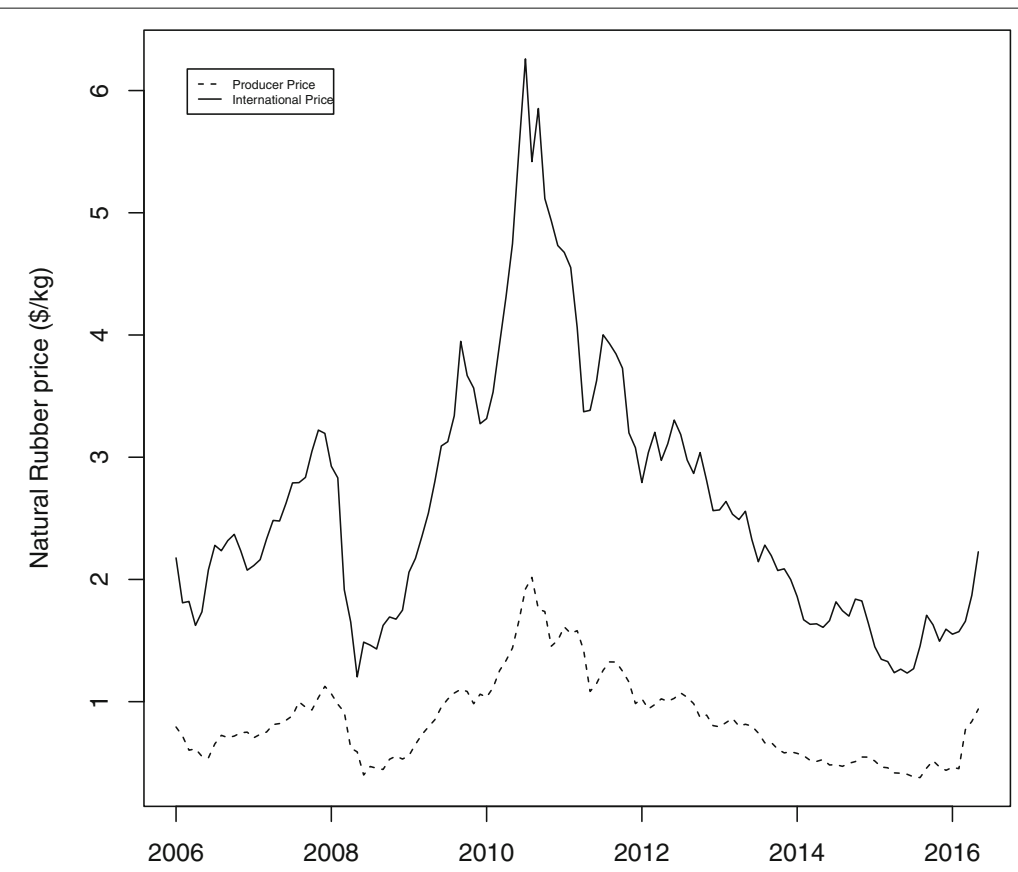

Fig. 2 Rubber monthly price from August 2006 to December 2016

The study is conducted using the logarithm of rubber prices. Logarithmic transformation of price series is very common in economic analysis. It allows a simple interpretation of the resulting coefficients as elasticities. Table 1 provides descriptive statistics of non-logged rubber price series.

\section{Methods}

A multivariate TVECM is used in the analysis to investigate the rubber price transmission mechanism between the world price and the Ivorian producer price and test for nonlinearity in the transmission process. Non-stationarity and co-movements of the prices are important time series properties to analyze beforehand. Since the sample covers a period with important shifts in the prices, tests allowing for structural breaks are needed.

\section{Unit root test in the presence of breaks}

Conventional unit root tests (e.g., ADF, KPSS, PP) ignore the existence of level shifts and are no longer valid in the presence of structural breaks in the data (Perron 1989). They might fail to reject the null hypothesis of a unit root while the data are actually stationary with the presence of breaks. Thus, when the variables considered are likely to contain breaks, it is more appropriate to use a unit root test allowing for breaks in the data. To

Table 1 Descriptive statistics for rubber prices in US dollar per kilogram

\begin{tabular}{lll}
\hline & World price $\left(P^{w}\right)$ & Producer price $\left(P^{d}\right)$ \\
\hline Mean & 2.623 & 0.852 \\
Minimum & 1.203 & 0.379 \\
Maximum & 6.259 & 2.017 \\
Standard deviation & 1.076 & 0.357 \\
No. of observations & 125 & 125 \\
\hline
\end{tabular}


this end, the test of Carrion-i Silvestre et al. (2009) hereafter (CKP) will be implemented in the study. The model uses the $M$ tests introduced in Stock (1999) and analyzed in Ng and Perron (2001). This test has several desirable properties: (a) it allows for multiple structural breaks both under the null and the alternative hypothesis, (b) it endogenously determines the break dates, (c) it uses generalized least square (GLS) detrending procedures. Gauss10 software was used for implementation. As for unit root tests, the presence of structural breaks tends also to affect standard cointegration tests and may result in biased estimators.

\section{Cointegration test in the presence of breaks}

In this paper, Johansen et al. (2000) (JMN) specification that includes dummy variables to account for structural breaks in the data was used. Giles and Godwin (2012) gave detailed explanations about $\mathrm{Hl}(r)$ and $\mathrm{Hc}(r)$ (respectively with a linear trend and a constant level) tests for cointegration built by Johansen et al. (2000) , with $r$ standing for the cointegrating rank. Breakpoints are denoted by $v_{j}=\left(T_{j} / T\right)$, where $T$ is the full sample size and $T_{j}$ is the last observation of the $j$ th sub-sample, $j=1,2, . ., q$. Including dummy variables to account for the different breaks, the vector autoregressive model (VAR) becomes :

$$
\Delta Y_{t}=\alpha\left(\begin{array}{c}
\beta \\
\gamma
\end{array}\right)^{\prime}\left(\begin{array}{c}
Y_{t-1} \\
t D_{t-k}
\end{array}\right)^{\prime}+\mu D_{t-k}+\sum_{i=1}^{k-1} \Gamma_{i} \Delta Y_{t-i}+\sum_{i=0}^{k-1} \sum_{j=2}^{q} K_{j, i} I_{j, t-i}+\epsilon_{t}
$$

$Y_{t}$ is a $p$ vector process, $\mu$ is a $p$ vector, $\epsilon_{t}$ is assumed purely random, and $D_{t}$ is a dummy variable. A detailed explanation of the specification of the dummy variables is provided by Joyeux (2007). The dummy variables are defined as follow:

$$
\begin{aligned}
D_{j, t} & =\left\{\begin{array}{l}
1 \text { for } T_{j-1}+1 \leq t \leq T_{j}, \text { for } j=2, \ldots q \\
0 \text { otherwise },
\end{array}\right. \\
D_{j, t-k} & =\left\{\begin{array}{l}
1 \text { for } T_{j-1}+k+1 \leq t \leq T_{j}+k, \text { for } j=2, \ldots q \\
0 \text { otherwise },
\end{array}\right. \\
I_{j, t} & =\left\{\begin{array}{l}
1 \text { for } t=T_{j-1}+1, \text { for } j=2, \ldots q \\
0 \text { otherwise. }
\end{array}\right.
\end{aligned}
$$

The cointegration hypothesis can be tested with the following likelihood ratio $(L R)$ statistic:

$$
\mathrm{LR}_{\mathrm{JMN}}=-T \sum_{i=r_{0}+1}^{p} \ln \left(1-\hat{\lambda}_{i}\right)
$$

\section{Price transmission and structural breaks}

To capture the potential impact of structural breaks on the transmission process, dummy variables to account for the two price spikes observed in 2008 and 2011 have been included in a linear VECM specification.

$$
\left\{\begin{array}{l}
\Delta P_{t}^{d}=\alpha\left(\mathrm{ECT}_{-1}\right)+\omega_{1} \Delta P_{t-1}^{w}+\omega_{2} \Delta P_{t-1}^{d}+\delta_{1} \Delta D_{t}^{08}+\delta_{1} \Delta D_{t}^{11}+v_{t} \\
\Delta P_{t}^{w}=\alpha\left(\mathrm{ECT}_{-1}\right)+\omega_{1} \Delta P_{t-1}^{d}+\omega_{2} \Delta P_{t-1}^{w}+\delta_{1} \Delta D_{t}^{08}+\delta_{1} \Delta D_{t}^{11}+v_{t}
\end{array}\right.
$$

with $\mathrm{ECT}_{-1}=P_{t-1}^{d}-\beta P_{t-1}^{w}-\gamma_{1} D_{t-1}^{08}-\gamma_{2} D_{t-1}^{11} P^{d}$ and $P^{w}$ stand respectively for the Ivorian rubber producer price and the rubber world price, $\alpha$ is the speed of adjustment parameter, and $\omega_{1}$ is the short-run world price elasticity. The step dummy variables $D^{08}$ 
and $D^{11}$ are part of the cointegrating vector. Differentiated variable $\Delta D^{08}$ and $\Delta D^{11}$ are impulse dummies included in the equation in order to capture the possible short-run effects of the structural changes in the data.

\section{Test for linearity against multivariate threshold cointegration}

Since the early proposal of Balke and Fomby (1997) to combine non-linearity and cointegration by the introduction of threshold cointegration, the model has generated significant interest. While Balke and Fomby (1997) tested for threshold cointegration in a univariate setting, Lo and Zivot (2001) extended their approach to a multivariate threshold cointegration with a known cointegrating vector using the tests of Tsay (1998) and multivariate extensions of Hansen (1996). Lo and Zivot (2001) proposed to test a threeregime TVECM against a linear VECM, a two-regime TVECM against a linear VECM, and a three-regime against a two-regime TVECM. Another significant contribution has been the paper of Hansen and Seo (2002) which extended the work of Lo and Zivot (2001) by allowing an estimation of a multivariate TVECM for an unknown cointegrating vector. This approach considers a VECM with one cointegrating vector and the error correction term (ECT) as a threshold variable. However, they proposed only a test for linear cointegration against a two-regime threshold cointegration. In our analysis, the null hypothesis of linear cointegration against multivariate threshold cointegration has been tested by following both approaches of Lo and Zivot (2001) and Hansen and Seo (2002). A three-regime threshold cointegration model takes the following form:

$$
\Delta y_{t}=\left\{\begin{array}{c}
A_{1}^{\prime} X_{t-1}(\beta)+\mu_{t} \text { if } w_{t-1}<\gamma_{1} \\
A_{2}^{\prime} X_{t-1}(\beta)+\mu_{t} \text { if } \gamma_{1} \leq w_{t-1} \leq \gamma_{2} \\
A_{3}^{\prime} X_{t-1}(\beta)+\mu_{t} \text { if } w_{t-1}>\gamma_{2}
\end{array}\right.
$$

where $\gamma_{1}$ and $\gamma_{2}$ are the threshold parameters, $y_{t}$ is a $p$-dimensional $I(1)$ time series which is cointegrated with one $p$ vector $\beta$ such as $w_{t}(\beta)=\beta^{\prime} y_{t}$ denotes the error correction term (ECT) and

$$
X_{t-1}(\beta)=\left(\begin{array}{c}
1 \\
w_{t-1}(\beta) \\
\Delta y_{t-1}
\end{array}\right) .
$$

If a threshold cointegration is not detected, then the simple linear VECM is considered.

\section{Impulse response function}

Impulse response functions are computed to get a better picture of the short-run dynamics between the variables. Impulse response functions are of interest in this empirical work as they represent marginal responses of the endogenous variables of the system to an impulse in one of them. For a stationary $\operatorname{VAR}(p)$ process $y_{t}$, the impulse response is basically derived from the moving average representation:

$$
y_{t}=\Phi_{0} u_{t}+\Phi_{1} u_{t-1}+\Phi_{2} u_{t-2}+\ldots,
$$

where $\Phi_{0}=I_{k}, k$ being the number of endogenous variables nad $p$ the number of lags of the VAR process $y_{t}$. $\Phi_{s}$ can be computed recursively as:

$$
\Phi_{s}=\sum_{j=1}^{s} \Phi_{s-j} A_{j}, \quad s=1,2, \ldots
$$


Table 2 Model with linear time trend and possible breaks in the intercept and slope

\begin{tabular}{lllllll}
\hline & Break 1 & Break 2 & DF-GLS & $M Z_{\alpha}^{G L S}$ & $M S B^{G L S}$ & $M Z_{t}^{G L S}$ \\
\hline$p^{w}$ & $2009-2008$ & $2002-2011$ & -2.731 & -20.589 & 0.142 & -2.924 \\
Critical values (5\%) & & & -3.858 & -30.164 & 0.128 & -3.858 \\
$p^{d}$ & $2008-2008$ & $2003-2011$ & -1.728 & -8.267 & 0.201 & -1.665 \\
Critical values (5\%) & & & -3.861 & -30.209 & 0.128 & -3.861 \\
\hline
\end{tabular}

We cannot reject the null hypothesis of unit root with presence of breaks

with $\Phi_{0}=I_{k}$ and $A_{j}=0$ for $j>p$. The coefficients of this representation may be interpreted as reflecting the response to impulses hitting the system. The $(i, j)$ th elements of the matrices $\Phi_{s}$, regarded as a function of $s$, trace out the expected response of $y_{i, t+s}$ to a unit change in $y_{j, t}$ holding constant all past values of $y_{t}$. The elements of $\Phi_{s}$ represent the impulse response of the components of $y_{t}$ with respect to the $u_{t}$ innovations (see Lütkepohl (2005) for further discussion). For non-stationary processes, the impulse response matrices $\Phi_{s}$ can be computed in the same way. The response of variable to a unit shock in another variable is depicted graphically for a visual impression of the dynamic interrelationships within the system. The impulse responses computed from the estimated VECM coefficients and bootstrap methods to construct confidence intervals were implemented in JMulTi.

\section{Results and discussion}

\section{Preliminary analysis}

Results from the CKP test support the presence of unit roots meaning that the series are non-stationary. As shown in Table 2, the results reveal that both $P^{d}$ and $P^{w}$ series are non-stationary with the presence of two structural breaks. The break dates which are determined endogenously are reported in Table 2. They correspond to huge increases in rubber prices. Given that the dates slightly differ for both series, we considered the largest interval between the two breaks, i.e., the first break occurring in August 2008 and the second break in March 2011.

As previous unit root tests suggested that both series are $I(1)$, the cointegrating relationship between them has been analyzed. Applying the JMN test which allows for breaks in the data, we cannot reject the hypothesis that both series are cointegrated. The results are summarized in Table 3.

\section{Linear VECM estimation}

The results of the estimated linear VECM have been reported in Table 4 and also include estimated parameters of the cointegration relationship as well as misspecification tests. The long-run elasticity is not statistically different from 1, meaning that world prices are perfectly transmitted to the domestic market in the long run. The positive link between both prices is not surprising, since the analysis is conducted in the post-liberalization

Table 3 Results of Johansen cointegration test

\begin{tabular}{lllll}
\hline$r$ & LR & $10 \%$ critical value & $5 \%$ critical value & $1 \%$ critical value \\
\hline$r=0$ & $66.13^{* * *}$ & 42.41 & 45.76 & 52.48 \\
$r \geq 1$ & 10.07 & 21.13 & 23.71 & 29.06 \\
\hline
\end{tabular}

Lag length for the test was chosen by Schwarz information criterion (SIC) and VAR residuals analysis; ${ }^{* * *}$ rejection of the null hypothesis at $1 \%$ significance level 
Table 4 Results of the linear VECM

\begin{tabular}{|c|c|c|c|}
\hline & ECT & $\Delta P_{-1}^{d}$ & $\Delta P_{-1}^{W}$ \\
\hline$p^{d}$ & $-0.196(0.0743)^{* *}$ & $0.031(0.0611)$ & $0.739(0.0937)^{* * *}$ \\
\hline$p^{w}$ & 0.169 (0.0983). & $0.125(0.0808)$ & $0.365(0.1239)^{* *}$ \\
\hline \multicolumn{4}{|c|}{ Cointegrating relationship : $p^{d}=1.20+1.08^{* * *} p^{w}$} \\
\hline LM test for autocorrelation & & 14.071 & \\
\hline$p$ value & & 0.296 & \\
\hline Multivariate ARCH-LM test & & 9.548 & \\
\hline$p$ value & & 0.388 & \\
\hline
\end{tabular}

period when producer prices started moving closely to international prices. The estimated value of the short-run elasticity between the rubber world price and the domestic price is statistically significant and about 0.75 . This elasticity value denotes a high rubber world price transmission to the Ivorian producer price in the short run. Recall that the data used are monthly. Greb et al. (2016) also find roughly $75 \%$ of the changes in international prices is transmitted to domestic markets, for cereals. However, we do not find perfect price transmission in the short run. As argued earlier in the introduction, taxes paid by farmers to ensure a good management of their professional organization could eventually constitute a barrier to the world price transmission. This is a potential explanation for finding incomplete price transmission between the international rubber price and producer prices in Côte d'Ivoire in the short run. As pointed by Kornher et al. (2013), price transmission appears to be rather incomplete, especially for African countries. Rapsomanikis and Mugera (2011) explained the incomplete price transmission as due to a large portion of transaction costs and agricultural policies. Through visual inspection of the time series of prices on Fig. 2, one could be struck by an estimation of transaction costs at more than $50 \%$ of the international price, but it is lower in reality. The graph also hides a difference in the quality between the rubber directly bought from farmers and the one traded on the international market. In fact, a part of the difference between the price series is explained by the humidity rate in $1 \mathrm{~kg}$ of rubber purchased from the producers that is therefore deducted from the price paid to them.

The estimated coefficient of the error correction term is -0.20 . This value represents the speed of adjustment. It suggests that $20 \%$ of the deviations from the equilibrium are corrected in a month. The negativity of this value confirms the return to the long-term equilibrium. Short-run dynamics are further discussed below with the help of the impulse response analysis. The dummy variables $D^{08}$ (August 2008) and $D^{11}$ (March 2011) have been included in the estimation of the linear VECM as specified in (3). Table 5 presents the estimated values of $\delta_{1}$ and $\delta_{2}$ which represent the short-run effect of the first and the second break, respectively. The non-significance of these parameters shows that the two structural breaks do not have any short-run impact on the price transmission process. As a consequence, important peaks in the price of natural rubber on the world market were also transmitted to the producer price in Côte d'Ivoire.

\section{Testing for linearity against threshold cointegration}

The results reported in Table 6 confirm our hypothesis. In fact, the null hypothesis of linear cointegration cannot be rejected at $5 \%$ level of significance. Our empirical results are in line with the Ivorian rubber sector organization. In fact, being a member of 
Table 5 Results of the VECM estimation with dummy variables

\begin{tabular}{llll}
\hline & Estimate & $t$ value & $p$ value \\
\hline$\alpha$ & $-0.194(0.076)$ & -2.585 & $0.010^{* *}$ \\
$\omega_{1}$ & $0.742(0.098)$ & 7.654 & $0.000^{* * *}$ \\
$\omega_{2}$ & $0.03(0.061)$ & 0.534 & 0.594 \\
$\delta_{1}$ & $0.002(0.067)$ & 0.028 & 0.978 \\
$\delta_{2}$ & $0.004(0.096)$ & 0.036 & 0.971 \\
\hline${ }^{\prime * * \prime \prime}$ and ${ }^{\text {"***" denote rejection }}$ of the null hypothesis respectively at 5\% and 1\% significance level. Standard errors are in parenthesis
\end{tabular}

interprofessional organization gives the producers a certain market power which countervails the power of agroindustrial firms. After the liberalization of the agricultural sectors in sub-Saharan Africa, the problem of declining market power of the producers has been raised. The entry of large private actors prevent producers from taking full advantage of the benefits of price liberalization. This has resulted in a low rate of elasticity of the producer price to the world price found in early studies, for most of the developing countries. The high elasticity and symmetric transmission found in this analysis show that the presence of a strong producers association can help to address the issue. We did not focus on the transmission from domestic to world prices since the country only holds a marginal share of the market. As stated in the "Background" section, Côte d'Ivoire's production is only about $2 \%$ of the world's production, which is not enough to influence world prices. This is confirmed by the second line of Table 4, which shows a weak and insignificant transmission of the domestic price to the world price.

\section{Impulse response function}

The impulse response function depicted in Fig. 3 illustrates the result of simulating a rubber producer price response to a permanent 1 standard deviation shock to the world price. A positive shock to rubber world prices leads to a new equilibrium characterized also by a higher producer price. The producer price increase is unexpectedly quick, since it requires only 5 months to complete. During the first 2 months, price increases are very large and quick and progressively slow down thereafter. After the third month following the rubber world price shock, the price is very close to its new equilibrium and further increases are very small. However, as expected, a shock in the domestic price has a statistically non-significant impact on the international price, since 0 lies in the confidence interval of the corresponding impulse response (see Fig. 4).

\section{Conclusion}

This paper aimed at examining the link between the rubber world price and the producer prices in Côte d'Ivoire. Two questions sustained this study. The first one was to analyze asymmetry in the transmission of rubber world prices to producer prices in Côte

Table 6 Summary of linearity tests

\begin{tabular}{llll}
\hline \multirow{2}{*}{ Estimates } & Hansen and Seo test & Lo and Zivot test & \\
\cline { 2 - 4 } & Linear vs threshold cointegration & Linear vs two regimes & Linear vs three regimes \\
\hline supLM test value & 11.97 & 13.69 & 39.83 \\
$p$ value & 0.66 & 0.43 & 0.11 \\
Critical value 95\% & 18.20 & 23.21 & 43.83 \\
\hline
\end{tabular}




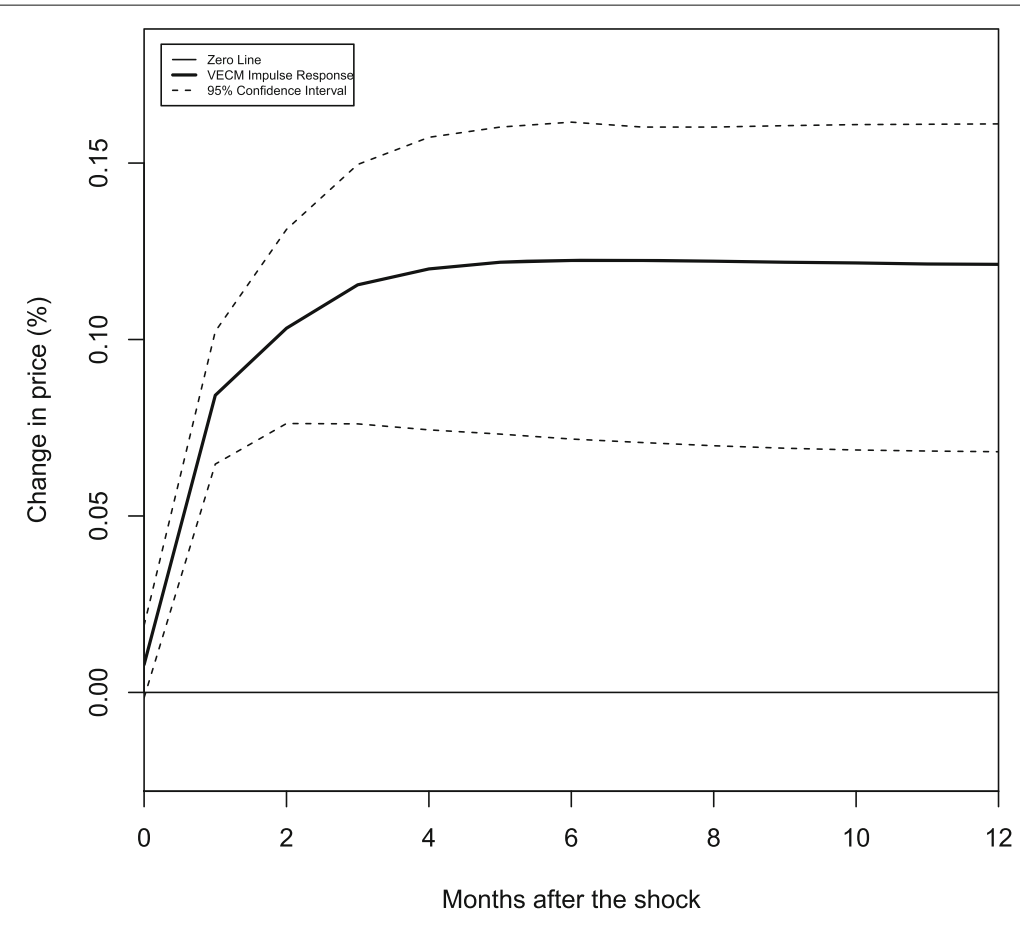

Fig. 3 Producer price response to a +1 standard deviation shock to the world price

d'Ivoire. The second one was to analyze the impact of important price spikes on the relationship between both prices. Monthly data from August 2006 to December 2016 were used for the study. To account for the shifts in the data, recent unit root and cointegration tests allowing for multiple structural breaks in the data were used. Our results suggest that the world price and the producer price move together in the long run and

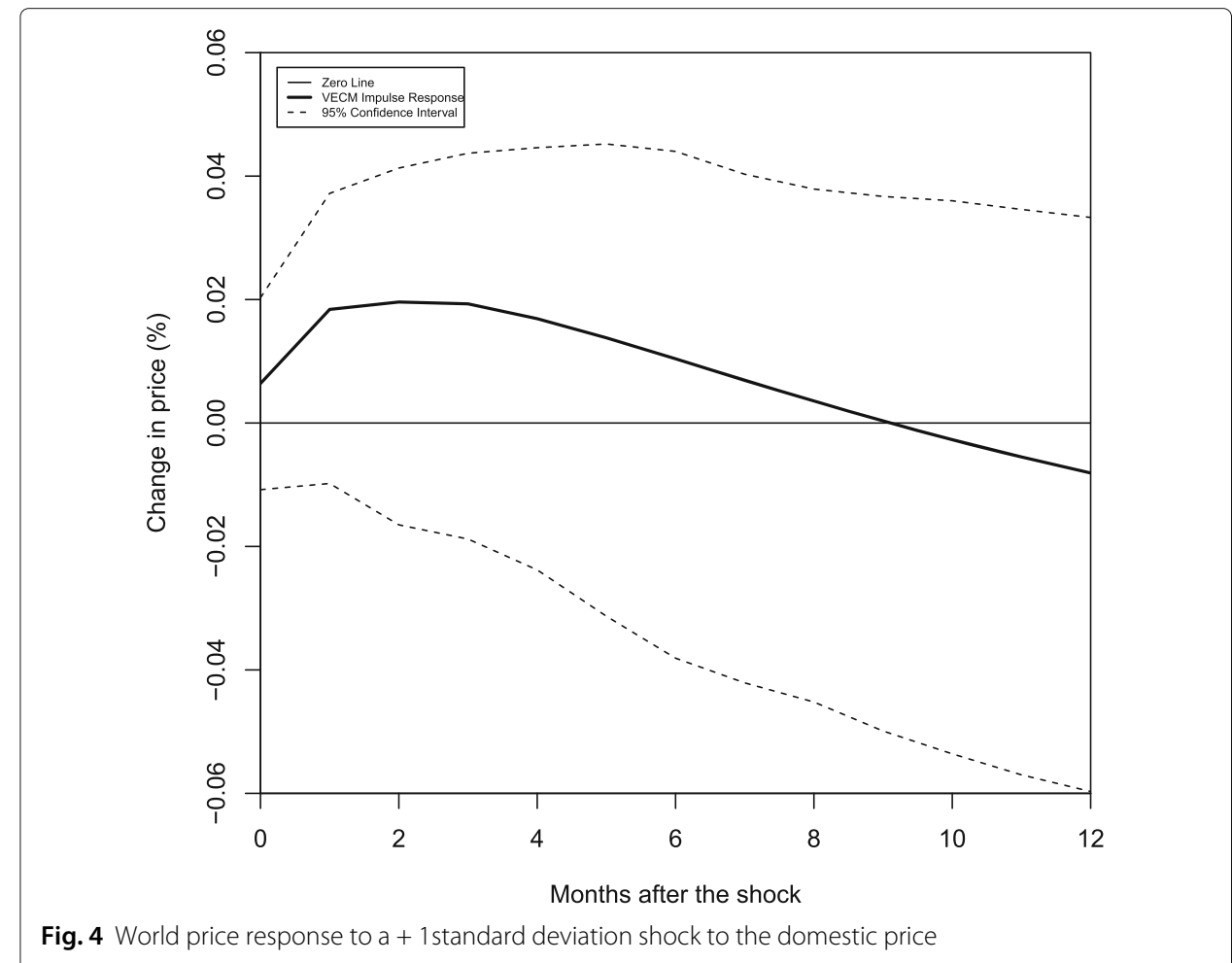


the transmission process does not present asymmetry. In the long run, world prices are perfectly transmitted to domestic prices, and the short-run elasticity is about 0.75 , which also means that changes in rubber world prices are highly transmitted to producer prices in the short run. Our results also provide evidence of structural breaks. These structural breaks have a non-significant short-run effect on the price transmission process. The results found are somehow surprising compared to the general trend of the other post-liberalized sectors, for which the studies highlight the presence of asymmetry in the transmission of world prices (Subervie (2007b), Badolo (2011)). However, when putting in parallel with the characteristics of the rubber industry, these results can be explained. The presence of an umbrella organization APROMAC within the rubber sector, which brings together all the actors and advocates for fair remuneration for the various players, has been able to somehow reduce the potential market power of agroindustrial firms, which results in a symmetric price response even in the presence of world spikes. However, the positive relationship between the two prices suggests that producers are also directly exposed to huge decreases in prices. This constitutes a threat for their revenue and needs to be addressed. Huge decreases in prices would not be a problem if the institutional context was favorable. However, rural areas are essentially characterized by missing financial markets, and this reduces the producers' ability to deal with the consequences of such price fluctuations. When credit or savings are constrained, smoothing consumption over time is obviously difficult. In addition, switching costs for perennial crops are huge. In this context, a state intervention could be justified. Furthermore, the fact that we do not find perfect price transmission in the short run is certainly due to the rigid parafiscal taxes made on monthly producer price for the management of the sector. These amounts, which do not depend on world prices, could reduce the estimated value of price transmission. A more general conclusion of this analysis is that increasing the producers' market power by improving the viability of professional agricultural organizations can help the producers to take more advantage of the benefits of the liberalization. However, policy-makers should be aware that the results also suggest that Ivorian producers are heavily exposed to world price fluctuations. This could be harmful in case of a sharp decrease in prices since financial markets are mostly missing in rural areas in developing countries. Thus, a price compensation mechanism should be introduced in this case. All these aspects and results above are to be taken into account in the implementation of the ongoing reform in the rubber sector in Côte d'Ivoire.

Since this topic has not been yet widely studied for export crops, this study serves as a starting point for future research into whether and to what extent world prices influence other export crops in Côte d'Ivoire.

\footnotetext{
Abbreviations

ADF: Augmented Dickey-Fuller; APPH: Association Professionnelle pour la Promotion Hévéicole; APROMAC: Association des PROducteurs et MAnucfacturiers de Caoutchouc en Côte d'Ivoire; CFA: Communauté Financière d'Afrique; CKP: Carrion-i-Silvestre, Kim and Perron; ECM: error correction model; FAO: Food and Agriculture Organization; FOB: Free on board; GLS: Generalized least square; JMN: Johansen-Moscow-Nielsen; KPSS: Kwiatkowski-Phillips-Schmidt-Shin; LR: Likelihood ratio; MGLS: Modified generalized least square; MIC: Modified information criteria; MINADER: Ministére Ivoirien de l'Agriculture et du Développement Rurale; PP: Philips-Perron; SIC: Schwarz information criterion; SICOM: Singapore Market Exchange; TVECM: Threshold vector error correction model; USD: United States dollar; VAR: Vector autoregressive; XOF: West African CFA Franc
}

\section{Acknowledgements}

We would like to thank the Agricultural and Food Economics team, the editor, and two anonymous referees for the helpful comments on earlier versions of the paper. We are also grateful to Prof. Bruno Henry de Frahan, Prof. José M.Gil, and Dr. Samuel Gbari for the advices to improve the manuscript. 


\section{Authors' contributions}

MA performed the econometric analysis and drafted the manuscript. FG conceived the research idea. Both authors participated in the interpretation of the result and read and approved the final manuscript.

\section{Funding}

Not applicable.

\section{Availability of data and materials}

The datasets used and/or analyzed during the current study are available from the corresponding author on reasonable request.

\section{Competing interests}

The authors declare that they have no competing interests.

Received: 7 June 2018 Accepted: 23 August 2019

Published online: 12 September 2019

\section{References}

Abdulai A (2000) Spatial price transmission and asymmetry in the Ghanaian maize market. J Dev Econ 63(2):327-349

Badolo F (2011) Transmission des chocs de prix internationaux: le cas du riz au burkina faso. CERDI, Etudes et Documents, E 2011.29. https://core.ac.uk/download/pdf/6476059.pdf

Baffes J, Gardner B (2003) The transmission of world commodity prices to domestic markets under policy reforms in developing countries. J Policy Reform 6(3):159-180

Balke NS, Fomby TB (1997) Threshold cointegration. Int Econ Rev 38:627-645

Carrion-i Silvestre JL, Kim D, Perron P (2009) GLS-based unit root tests with multiple structural breaks under both the null and the alternative hypotheses. Econom Theory 25(6):1754-1792

Giles DE, Godwin RT (2012) Testing for multivariate cointegration in the presence of structural breaks: p-values and critical values. Appl Econ Lett 19(16):1561-1565

Greb F, Jamora N, Mengel C, Cramon-Taubadel V, Wurriehausen N (2016) Price transmission from international to domestic markets. World Bank, Washington, DC

Hansen BE (1996) Inference when a nuisance parameter is not identified under the null hypothesis. Econometrica 64:413. https://doi.org/10.2307/2171789

Hansen BE, Seo B (2002) Testing for two-regime threshold cointegration in vector error-correction models. J Econ 110(2):293-318

Hazell PB, Jaramillo M, Williamson A (1990) The relationship between world price instability and the prices farmers receive in developing countries. J Agric Econ 41(2):227-241

Johansen S, Mosconi R, Nielsen B (2000) Cointegration analysis in the presence of structural breaks in the deterministic trend. Econ J 3(2):216-249

Joyeux R (2007) How to deal with structural breaks in practical cointegration analysis. In: Rao BB (ed). Cointegration: for the Applied Economist, chapter 7. palgrave macmillan, New York. pp 266-290

Jutting J (2005) Transmission of price shifts in the context of structural adjustment: an empirical analysis for staple food after the devaluation of the franc cfa in ivory coast. Agric Econ 22(1):67-74

Kornher L, Kalkuhl M, et al. (2013) Food price volatility in developing countries and its determinants. Q J Int Agric 52(4):277-308

Kouame JB (2015) Les facteurs du developpement de l'heveaculture en côte d'ivoire de 1994 à 2012. Eur Sci J, ES 11(17):202-219

Lloyd TA, Morgan CW, Rayner AJ, Vaillant C (1999) The transmission of world agricultural prices in côte d'ivoire. J Int Trade Econ Dev 8(1):125-141

Lo MC, Zivot E (2001) Threshold cointegration and nonlinear adjustment to the law of one price. Macroecon Dyn 5(4):533-576

Lütkepohl H (2005) New introduction to multiple time series analysis. Springer, Heidelberg

MINADER (2016) Réforme des filières Hévéa et Palmier à huile Document de stratégie. Ministère Ivorien de L'Agriculture et du développement Rural, Abidjan

Minot N (2010) Transmission of world food price changes to markets in Sub-saharan Africa. International Food Policy Research Institute, Washington

Mundlak Y, Larson DF (1992) On the transmission of world agricultural prices. World Bank Econ Rev 6(3):399-422

$\mathrm{Ng}$ S, Perron P (2001) Lag length selection and the construction of unit root tests with good size and power. Econometrica 69(6):1519-1554

Perron P (1989) The great crash, the oil price shock, and the unit root hypothesis. Econometrica 57(6):1361. https://doi. org/10.2307/1913712

Quiroz JA, Soto R (1995) International price signals in agricultural markets: do governments care? ILADES-UAH Working Papers, 88. http://fen.uahurtado.cl/wp-content/uploads/2010/07/inv88.pdf

Rapsomanikis G, Mugera H (2011) Price transmission and volatility spillovers in food markets of developing countries. In Piot-Lepetit I., MR., editor, Methods to analyse agricultural commodity price volatility, chapter 10. Springer, New York. pp 165-179

Ruf F (2012) L'adoption de l'hévéa en côte d'ivoire. prix, mimétisme, changement écologique et social. Économie Rurale 330-331:103-124. https://doi.org/10.4000/economierurale.3527

Sharma R (2003) The transmission of world price signals: the concept, issues, and some evidence from asian cereal markets. In Brooks, J., editor, Agricultural Trade and Poverty: Making Policy Analysis Count, chapter 2. OECD Publications, Paris. pp 141-160 
Shepherd AW, Farolfi S (1999) Libéralisation du secteur des cultures d'exportation en Afrique, bilan, vol 135. Bulletin des services agricoles de la FAO, Rome

Soumahoro S (2017) Export taxes and consumption: evidence from côte d'ivoire s de facto partition. Econ Dev Cult Chang 65(3):425-456

Stock JH (1999) A class of tests for integration and cointegration. In Cointegration, Causality and Forecasting. A Festschrift in Honour of Clive WJ Granger, chapter 6. Oxford University Press, Oxford. pp 137-167

Subervie J (2007a) La transmission de l'instabilité des prix agricoles internationaux et ses conséquences dans les pays en développement. PhD thesis. Université d'Auvergne-Clermont-Ferrand I

Subervie, J (2011) Producer price adjustment to commodity price shocks: An application of threshold cointegration. Econ Model 28(5):2239-2246

Subervie J (2007b) Rupture et asymétrie de la transmission des prix agricoles internationaux. CERDI, Etudes et Documents, E 2007.22. http://publi.cerdi.org/ed/2007/2007.22.pdf

Tsay RS (1998) Testing and modeling multivariate threshold models. J Am Stat Assoc 93(443):1188-1202

von Cramon-Taubadel S (2017) The analysis of market integration and price transmission : results and implications in an african context. Agrekon 56(2):83-96

\section{Publisher's Note}

Springer Nature remains neutral with regard to jurisdictional claims in published maps and institutional affiliations.

\section{Submit your manuscript to a SpringerOpen ${ }^{\circ}$ journal and benefit from:}

- Convenient online submission

- Rigorous peer review

Open access: articles freely available online

High visibility within the field

- Retaining the copyright to your article

Submit your next manuscript at $\gg$ springeropen.com 